\title{
Semantic Conflict and Response Conflict in the Stroop Task
}

\author{
Alexey Starodubtsev \\ Department of Psychology, St. Petersburg State University, Russia
}

\section{Mikhail Allakhverdov}

Faculty of Liberal Arts and Sciences, St. Petersburg State University, Russia

\begin{abstract}
The most common ways researchers explain the Stroop effect are either through semantic or through response conflict. According to the literature, there are several methods capable of disentangling these conflicts: to use words outside of the response set, to use associatively related colors and words, or to use a "2:1" paradigm (requiring the same response for two types of stimuli). However, we believe that these methods cannot entirely differentiate semantic and response conflicts. We propose the following alternative method: when naming the color of a printed word (e.g., red, yellow, etc.) in the Stroop test, participants were asked to use different color names for some colors. For example, the red-colored stimuli had to be named by the word "yellow". This approach allowed us to create semantically congruent stimuli, but with the conflict at the response level (the word red appears in red, but the participants have to say "yellow" because of the rule). Some stimuli remain congruent at the response level, but with the conflict at the semantic level (the word yellow appears in red, and the participants have to say "yellow" because of the rule). The results showed that semantically congruent stimuli do not produce the Stroop effect even if the meaning of the word corresponds to an incorrect response. In turn, congruence at the response level reduces the interference effect, but interference remains significant. Thus, the response conflict affects the magnitude of the Stroop effect only when there is a semantic conflict. Our data do not correspond to models that assume direct activation of responses corresponding to word meaning.
\end{abstract}

Correspondence: Alexey Starodubtsev, fleksbr@yandex.ru, St. Petersburg University, 7/9 Universitetskaya nab., 199034 St. Petersburg, Russia; Mikhail Allakhverdov, m.allakhverdov@smolny.org.

Keywords: Stroop test, interference, semantic conflict, response conflict, automaticity, attention

Copyright (C) 2019. Alexey Starodubtsev, Mikhail Allakhverdov. This is an open-access article distributed under the terms of the Creative Commons Attribution License (CC BY), which permits unrestricted use, distribution, and reproduction in any medium, provided that the original authors are credited and that the original publication in this journal is cited, in accordance with accepted academic practice.

Note. The article is partially based on an earlier paper reporting preliminary results in the conference proceedings volume: Starodubcev, A. (2019). [The role of the semantic and response conflicts in the occurrence of the Stroop effect]. In E. V. Pechenkova \& M. V. Falikman (Eds.), [Cognitive Science in Moscow: New Research. 2019 Conference proceedings] (pp. 490-495). Moscow: Buki Vedi, IPPiP.

Acknowledgements. The research was supported by RFBR (Project number 18-013-01212).

Received September 30, 2019, accepted December 27, 2019.

\section{Introduction}

The classic Stroop effect (interference) is the delay in reporting the color of ink in which the name of a color is printed, when the meaning of the word and the ink color are different (Stroop, 1935). Such stimuli are called 'incongruent' (e.g., the word red in blue ink). In most cases, researchers consider a time delay relative to the time of naming the color of an unreadable string of characters (e.g., XXXXXX).
Kinoshita, with colleagues, noticed: "It is widely agreed that the Stroop effect reflects a conflict between the color and the to-be-ignored word, but much is still not known about the nature of that conflict" (Kinoshita, de Wit, Aji, \& Norris, 2017 , p. 824). Words are characterized by multiple parameters, each of which can influence the effect of interference: the fact of the presence of a word as such, the belonging of the word to the category of "color," the associative relation between the meaning of the word and its color, the overlap 
of the meaning of the word in a given trial with the correct response to previous test trials (Sharma \& McKenna, 1998).

The conflict between the font color of a word and its meaning may occur at different stages of information processing. In the early processing stages, the physical features of the stimulus are analyzed; then the stimulus is semantically processed; and the response to the stimulus is prepared in the latest stages. Accordingly, three types of conflict situations are identified in the literature, which affect the speed and accuracy of task performance: task conflict, semantic conflict, and response conflict, respectively. Task conflict reflects the influence of the process of reading the word. Because the reading process is not relevant to the task, it conflicts with the task of naming the ink color. However, the task conflict factor is weaker in terms of response speed compared to semantic conflict or response conflict (Lupker \& Katz, 1981). It is believed that the influence of task conflict can be found only in specific conditions. Kalanthroff and co-authors conclude that in conditions where there is only a small number of control stimuli (in most experiments, less than half), the "task conflict does not arise (or is resolved very quickly)" (Kalanthroff, Davelaar, Henik, Goldfarb, \& Usher, 2017, p. 1).

Semantic conflict reflects the impact of conflicting representations of a word's meaning and color. At this stage of information processing, the recognition of the color of the word and its meaning has already been completed, but the corresponding responses have yet to be formed. The conflict at this stage of processing is denoted in a different way depending on the researchers' understanding of interference mechanisms. For example, if interference is described in connection with word processing, the conflict is called "lexical" (the earlier stage, in this case, is called "pre-lexical" and the later stage is called "post-lexical"; see, for example, Brown, Roos-Gilbert, \& Carr, 1995). If the researchers assume that a decision is made to "translate" characteristics of the stimuli into the corresponding response, the stage is called "conflict at the decision level" (Sharma \& McKenna, 1998), or simply by the word "decision" in quotation marks (Stafford \& Gurney, 2011). Similar concepts lie behind the terms "perceptual conflict" (Bekci \& Karakas, 1985; Doehrman, Landau, \& O'Connel, 1978) or "stimuli-stimuli conflict" (Wendelken, Ditterich, Bunge, \& Carter, 2009). The authors may have different interpretations of information processing at this stage and sometimes do not distinguish between semantic and task conflicts (e.g., Steinhauser \& Hubner, 2009). However, semantic conflict and response conflict get distinguished more often.

Response conflict has been traditionally believed to be a significant factor of interference (Dyer \& Severance, 1973; Lupker \& Katz, 1981). The main assumptions of the response conflict hypothesis are: a person cannot simultaneously name both the ink color and the meaning of a word, the meaning of a word has priority in processing in comparison with its ink color (because the meaning of the word is processed more quickly or because reading is an automatic process, unlike the processing of a word's font color). There are also modern models which explain interference by the time-consuming suppression of an irrelevant answer (see Janssen, Schirm, Mahon, \& Caramazza, 2008).

Nevertheless, there are also hypotheses of semantic conflict as the main cause for interference (Luo, 1999).
The majority of scientists accept the presence of both semantic conflict and response conflict. In many ways, such a difference in positions is due to different methods of separating the semantic conflict from the response conflict. Let us look more closely at the methods that allow us to disentangle the influence of the response conflict and the semantic conflict in experiments.

\section{Methods that Differentiate Semantic and Response Conflicts}

Methods that induce only the semantic conflict without any response conflict use different approaches to prevent participants from making an erroneous response that matches to the meaning of the word. Researchers have widely accepted the list of procedures laid out by Parris and colleagues (Parris, Wadsley, Hasshim, Benattayallah, Augustinova, \& Ferrand, 2019) that describe essential steps for disentangling semantic and response conflicts: to use words outside of the response set, to use semantically related words and colors, and to use the button that matches either to the color or to the meaning of the incongruent stimulus.

The first method is to use words which are not part of the response set. For example, if the colors of the stimuli can only be red or blue, then the response set for the colornaming task consists of the elements red and blue. However, the meanings of words outside of the response set (e.g., the word green appearing in blue for the case described above) still produce an interference effect, although the effect is significantly reduced compared to trials that use words within the response set (e.g., the word red in blue) (e.g., Sharma \& McKenna, 1998; Wadsley, 2019).

The second way to differentiate the influence of semantic conflict and response conflict in an experiment is to use words associatively connected with correct responses. For example, a participant is slower to name the ink color of the word water printed in red, than the word water printed in blue. Since the relation between the meaning of the word water and the ink color of its font do not correspond directly to the responses, the interference in case of the word water printed in red suggests only a semantic conflict (e.g., Augustinova, Parris, \& Ferrand, 2019; Harrison \& Boese, 1976).

Finally, the third way to induce a semantic conflict without a response conflict is to use tasks in which two different types of stimuli require the same response $(2: 1$ paradigm). The instruction for participants is to give one response (for example, to press a button) if the stimulus is either red or blue. In this case, the word red in blue color will be semantically conflicting. Still, both the color and meaning correspond to the same response, and therefore this stimulus will be congruent at the response level (e.g., Hasshim \& Parris, 2015; Schmidt, Hartsuiker, \& De Houwer, 2018; Shichel \& Tzelgov, 2017; Steinhauser \& Hubner, 2009).

\section{Criticism of Traditional Approaches Utilized to Differentiate Semantic and Response Conflicts}

The methods of disentangling different types of conflicts are based on assumptions that may seem flawed. For example, are the meanings of words outside of the response set 
not processed at the response level? It seems plausible that a response conflict in words outside of the response set is attenuated, but not absent. Nonetheless, some authors use response conflict to explain the results of experiments in which they used only words outside of the response set (for example, see Janssen et al., 2008). Another line of criticism is that the response set draws participants' attention to certain physical features of the stimuli. If the participants' responses can only be "red" or "blue", then they will pay attention to the words which are similar to these responses. The response set can also influence the semantic processing of the stimulus. It is known, for example, that expecting a certain stimulus affects the effectiveness of its subsequent recognition (effect of the perceptual set). By analogy, a response set may also affect the semantic processing of word meanings.

The effect of an associative connection between the color of a word's appearance and its meaning may also carry a conflict at the response level. For example, presenting the word grass will speed up the subsequent response "green." Similarly, the word water may pave the way for the response "blue". Therefore, presenting the word water in red may cause a conflict of the responses "red" and "blue," i.e., a reduced response conflict. Schmidt, Cheesman, and Besner (2013) showed that the effect of an "associative conflict" (the word grass in red) only occurs when the word "green" belongs to the response set. In the authors' opinion, it is the response "green" that competes with the word "red" if the word grass is presented in red, but there is no semantic conflict between the word grass and the response word "red." Indeed, Schmidt and colleagues showed that in tasks other than the Stroop test (the task of reading words, lexical decision task), the word "red" speeds up the subsequent processing of the word grass.

For this reason, we cannot exclude the influence of the response conflict in the case of the semantic relation of a word's meaning and its color. In Riley's work with coauthors (Riley, McMahon, \& de Zubicaray, 2015) in the picture-word paradigm", the data suggest that the "semantic conflict" may vary if participants familiarized themselves with the permitted responses before the experiment. This further complicates the possible ways to disentangle semantic and response conflicts.

Using the " $2: 1$ " paradigm seems to be the most reliable way to trigger a semantic conflict without a conflict of responses. However, in the experiments known to us, the 2:1 paradigm was used only in the motor versions of the Stroop task (manual or oculomotor). In such a procedure, participants are asked not to name the ink color aloud but to make a particular movement with their hand or eye, which has been assigned as corresponding to a specific color before the experiment. In the study of Hasshim and Parris (2015), participants responded by moving their eyes. For instance, if the stimulus was blue or green, it was required to look at one of the squares displayed on a screen, while if it was red or yellow, then they were expected to look at another square. In a study by van Veen and Carter (2005), participants had to press buttons. For example, participants should press one button if the stimulus was green or blue, and another button if the stimulus was red or yellow. In this

\footnotetext{
1 In this paradigm, the participants name the images and ignore the words placed over them. The picture-word paradigm is one of the closest analogs to the classical Stroop test (see Starreveld \& La Heij, 2017).
}

task, the word green appearing in blue was semantically conflicting but congruent at the response level (the meaning of the word and its color corresponded to the same response). The congruence at the response level was sufficient to significantly reduce or eliminate the Stroop effect.

Nevertheless, the motor Stroop task is considerably different from the task of overt naming of ink color. In color naming, a processing priority for word meaning has been revealed. Word meanings affect the speed of color naming, while ink color does not influence reading speed (Stroop effect asymmetry; Glaser \& Glaser, 1982). This is not the case for the motor Stroop task. When using keyboard presses or mouse clicks to respond to word meaning, participants react slower when the word meaning is incongruent to the ink color (reverse Stroop effect; Durgin, 2000).

It is well-known that participants more quickly compare the color of a filled rectangle with the font color of the word rather than with the word's meaning (e.g., Luo, 1999). This fact often contributes to the critique of the conflict response hypothesis. After all, if the word gets priority in processing, then participants should match the meaning of a word with the color of a rectangle faster than matching the color of a word with the color of a rectangle. Such criticism may seem weak because, in this case, the task considerably differs from the classical Stroop task. In our opinion, the use of non-classical methods should be justified either logically or by the results of experiments. However, even the motor (manual) Stroop task does not comply with this requirement. For example, in the oral version of the Stroop test, there is a negative priming effect: participants are slower to name the ink color of a word if the color matches the meaning of the previous word. This effect can be interpreted via the response conflict hypothesis: the suppression of a response that corresponds to the meaning of a word extends to the processing of the next stimulus, in which this response is already the correct response to the task. However, no negative priming effect was found in the manual Stroop test (Mills, Kinoshita, \& Norris, 2019).

Moreover, the difference between the manual and oral versions of the Stroop test is indicated in the study of Sharma and Makenna (Sharma \& McKenna, 1988). In their experiment, different stimuli featured one or several components of interference: lexical, semantic relatedness, semantic relevance, and response set membership. A colored set of " $\mathrm{X}$ " characters (XXXXXX) does not contain any of these components; neutral words (table, nail) include only the lexical factor; words related to color (sea, grass) contain the semantic relatedness component; colored words outside of the response set (orange, white) contain elements of semantic relevance; and classical Stroop stimuli include all described components. Each of the components increased interference in the oral Stroop test. Still, only response set membership influenced the interference level in the manual version of the Stroop test. This suggests that the oral and manual versions of the Stoop test cannot be used as interchangeable methods, at least not when studying the roles of semantic and response conflicts.

\section{Study Rationale}

Thus, most often, semantic and response conflicts get separated either by varying the response set, by associative connection, or by using the " $2: 1$ " paradigm. Variation of the response set and associative connection allow for 
interpretation with conflicts at the response level only. The "2:1" paradigm has so far been used only in the motor versions of the Stroop task. For these reasons, our first goal was to reproduce the " $2: 1$ " paradigm in the oral Stroop test.

Another motivation for our research is that the description of different types of conflicts in modern works on Stroop interference could be simplified. We believe that the co-presence of many types of conflicts (and many types of "control" over these conflicts) is logically redundant. For example, if there is a semantic conflict that should be resolved to accomplish the task correctly, there should be no response conflict. If the meaning of the word is suppressed at the response level, then there is no need to suppress it at the semantic level as well.

\section{Study Design}

In our study, we planned to evoke a "pure" conflict at either the response level or the semantic level in the oral Stroop task. In the oral Stroop test, two colors were to be renamed with other color labels (the idea for this method was suggested in a theoretical paper by Arbekova and Gusev, 2017). For example, participants should say "yellow" in response to red stimuli. Let us consider the experimental conditions that can be implemented with such an approach. In this case, the word red appearing in red is presented when the participants should call the red stimuli by the word "yellow." On the one hand, the meaning of the word does not activate the correct response for the task. On the other hand, there are more sources of information related to the representation of "red" on the semantic level. In some cases, redundant information speeds up the responses (Utochkin \& Bolshakova, 2010).

Another condition that is important for us is matching the meaning of a word with the correct response in the case of a semantic conflict. For example, the participant has to say "red" in response to the yellow stimulus, and the stimulus is the word red in yellow ink. The color is not the same as the meaning (semantic conflict), but the meaning of the word is the same as the participant's response. We expect that this design will allow us to distinguish between a conflict at the response level and a semantic conflict.

The proposed experiment implements not only the "semantic conflict without response conflict" con- dition but also the "response conflict without semantic conflict" condition. Thus, the main aim of the research is to find out whether the factors of "the response conflict" and "the semantic conflict" are independent of each other. Examples of the stimuli that are implemented with our method are given in Table 1.

\section{Experiment}

\section{Method}

Participants. Twenty-four individuals participated in the study. They were from 18 to 40 years old $(M=24.4$; $S D=5.8)$ (7 men and 17 women). Participation in the experiment was part of the "Experiment Week" event. Respondents received no compensation for participating in the study.

Equipment. Stimuli were presented on the LCD of a desktop computer with a noise-suppressing microphone; the distance from the participant's eyes to the display screen was $50-60 \mathrm{~cm}$. LCD monitor characteristics: diagonal 24" (61 cm); display width: $53 \mathrm{~cm}$; display height: $29.5 \mathrm{~cm}$; resolution: $1920 \times 1080 \mathrm{px}(16: 9)$; refresh rate: $60 \mathrm{~Hz}$ (with maximum of $144 \mathrm{~Hz}$ ). The presentation of stimuli and recording of responses was performed with the help of PsychoPy 2 software. The time interval between the appearance of a stimulus and the beginning of the response, as well as the correctness of the vocalization, were calculated manually in the Praat program.

Stimuli. Neutral stimuli: "XXXXXX" characters displayed in blue, green, red, or yellow. Congruent stimuli: The words red, blue, yellow, and green displayed in the color that matches their meaning. Incongruent stimuli: words written in colors that do not match their meaning; that is, the words red, blue, yellow and green printed in one of the other three colors. All color-meaning combinations for the condition "incongruent stimuli" appeared an equal number of times during the experiment.

There were 12 rules for color naming. For example, one of the rules was to call red stimuli "blue" and to say "green" in response to the yellow stimulus. Each participant was assigned one of the 12 rules.

Procedure. Before the experiment, we assigned each participant a rule of color naming using the Latin

Table 1. Example of Experimental Conditions for the Rule "Blue Stimuli Should be Called 'Red'; Red and Green Colors Should be Called the Usual Way"

\begin{tabular}{|c|c|c|c|c|c|}
\hline \multirow{2}{*}{$\begin{array}{l}\text { Example } \\
\text { of Stimuli }\end{array}$} & \multirow{2}{*}{ Correct Response } & \multicolumn{2}{|c|}{ Formal Stimulus Attribute } & \multirow{2}{*}{$\begin{array}{l}\text { Matching the } \\
\text { Meaning of the Word } \\
\text { and its Color }\end{array}$} & \multirow{2}{*}{$\begin{array}{l}\text { Matching the Meaning } \\
\text { of the Word } \\
\text { and the Correct Response }\end{array}$} \\
\hline & & Congruency & Type of Naming & & \\
\hline RED & «red» & congruent & same color & Yes & Yes \\
\hline BLUE & «red» & congruent & another color & Yes & No \\
\hline$X X X X$ & «red» & neutral & same color & - & - \\
\hline$X X X X X$ & «red» & neutral & another color & - & - \\
\hline BLUE & «green» & incongruent & same color & No & No \\
\hline YELLOW & «red» & incongruent & another color & No & No \\
\hline RED & «red» & incongruent & another color & No & Yes \\
\hline
\end{tabular}




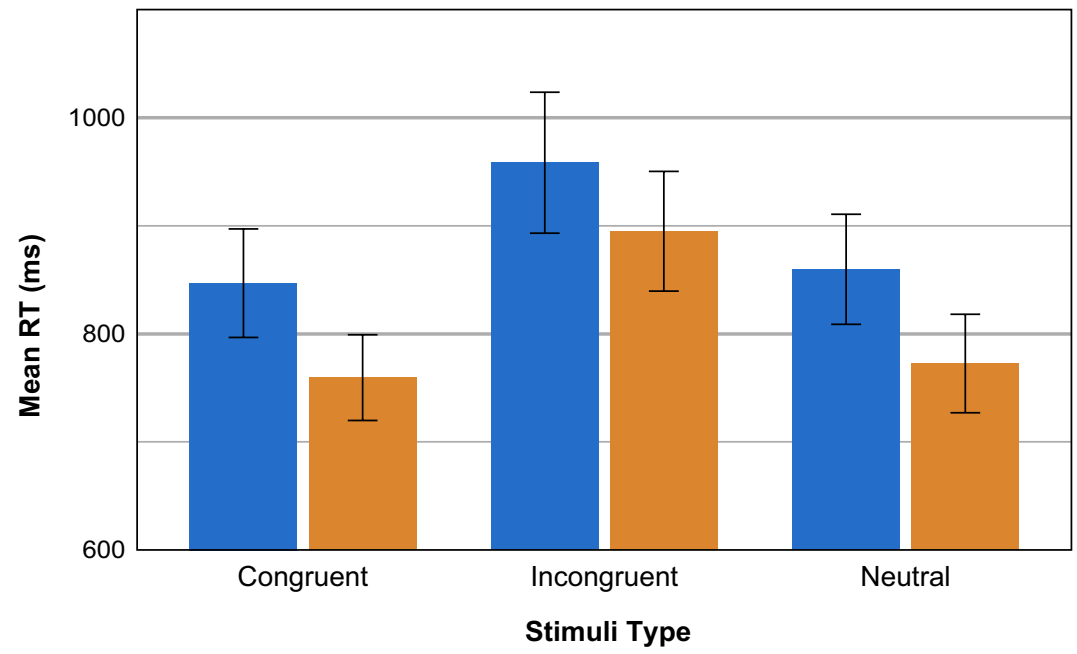

Naming

Other Colors

Same Colors

Figure 1. Average response time, depending on stimulus type and color naming type. Error bars represent the $95 \%$ confidential interval

square method. They had to name two of the used colors in the usual way and use specific different names for the two other colors (e.g., "blue" instead of "green", and "yellow" instead of "red"). During the practice stage, participants received the instruction to answer as accurately as possible without worrying about the time. In the experimental stage, the task was to respond as quickly as possible. We also informed participants that any extraneous sounds ("aaa," "mmm," etc.) and word stretching and drawling ("bluuue") would count as errors.

In the two first stages of the procedure, participants were practicing the unfamiliar naming. In the first stage, they pronounced the colors of 60 neutral stimuli (4 color variants). In the second stage, they named 36 stimuli that could be neutral, incongruent, or congruent. The stimuli appeared one by one on a grey background, written in Arial upper case (on average $8 \mathrm{~cm}$ wide and $1 \mathrm{~cm}$ high).

In the first two stages, the participants had to press the space bar to start the next trial. The experimenter sat next to them and, if necessary, reminded them of the rule or called their attention to their errors. In the third stage, the participants had to perform the test on their own. The sequence of presentation within a trial was as follows: an empty screen - $1000 \mathrm{~ms}$; a fixation cross - $300 \mathrm{~ms}$; a blank screen - $400 \mathrm{~ms}$; and the Stroop stimulus - $1700 \mathrm{~ms}$. After this time passed, the next stimulus appeared no matter how the participants answered or whether they responded at all. There were 144 stimuli in total, a third of which were congruent, a third were incongruent, and the remaining stimuli were neutral (factor: type of stimuli); half of the trials presented a stimulus that was to be named in the regular way, and the other half required the rule-modified naming (factor: type of naming). The stimuli presentation order was random, but there were no repetitions of color, meaning, or congruence more than three times in a row; repetition in terms of naming type was restricted to no more than five times in a row.

\section{Results}

We counted partially or fully wrong answers and external vocalizations as errors. We removed them from further analysis: $3.5 \%$ for congruent stimuli, $8 \%$ for noncongruent stimuli, and $3.1 \%$ for neutral stimuli in the case of regular color names; $1.9 \%, 6.4 \%$, and $2.8 \%$, respectively, in the case of color names modified by the rule. Only the correct response times were further analyzed. Figure 1 shows the average time for correct responses as a function of "naming type" and "stimulus type" factors.

In the analysis of the factor "type of stimulus", Mauchly's test found significant deviations from sphericity $(\mathrm{W}=.408, \mathrm{p}<.001)$, and therefore we performed repeatedmeasures ANOVA (with factors "stimulus type" and "type of naming", and "participant number" as a grouping variable) with Greenhouse-Heisser correction. The influence of the factors "type of stimulus" (congruent, neutral, and incongruent) and "type of naming" (the same colors, the other colors) was statistically significant: $F(2,46)=69$, $\eta_{\mathrm{p}}^{2}=.65, \quad p<.001$ and $F(1,23)=46, \quad \eta_{\mathrm{p}}^{2}=.70, \quad \mathrm{p}<.001$. The interaction of factors was not statistically significant $\left(F(2,46)=1.25 ; \eta_{\mathrm{p}}^{2}=.05, \mathrm{p}=.29\right) \quad$ (Figure 1). Post hoc power analysis revealed high power for all observed effects (Observed Power $=1$ ).

Post hoc analysis of the "stimulus type" factor with Bonferroni correction revealed a slower response to incongruent stimuli $(M=927 \mathrm{~ms} ; S D=27 \mathrm{~ms})$ compared with the speed of responses to neutral $(M=816 \mathrm{~ms} ; S D=23 \mathrm{~ms})$ and congruent stimuli $(M=803 \mathrm{~ms} ; S D=22 \mathrm{~ms})$. Both differences were statistically significant $(M D=123 \mathrm{~ms} ; S E=13$; $p<.001$ and $M D=110 \mathrm{~ms} ; S E=17 ; p<.001)$. Participants were significantly slower in responding if it was necessary to use another label for the color of the stimuli $(M D=79 \mathrm{~ms}$; $S E=12)$. All averages are shown in Figure 1.

In the reported analysis, we did not account for the semantically conflicting stimuli that were congruent at the response level (e.g., it is the word red in yellow color when the instruction is to name yellow stimuli with the word "red"). Each participant faced eight such "response-congruent" stimuli. In our experiment, we made equal proportions of stimuli of each type, color, and meaning because otherwise, we would face artifacts of associative learning or expectancy effects. Therefore, there were not many "response-congruent" stimuli. However, we reused part of our data to analyze response times specifically for the "response-congruent" stimuli. Response times to "response-congruent" stimuli were compared with response times to congruent stimuli (another color 
naming condition) and other incongruent stimuli (another color naming condition, but not response-congruent). Response time to response-congruent stimuli was on average smaller than response time to other incongruent stimuli $(M=908 \mathrm{~ms}, S D=44 \mathrm{~ms}$ vs. $M=958 \mathrm{~ms}, S D=32 \mathrm{~ms})$, but longer than response time to congruent stimuli $(M=908 \mathrm{~ms}, S D=44 \mathrm{~ms}$ vs. $M=848 \mathrm{~ms}, S D=24 \mathrm{~ms})$. Both differences were statistically significant: $t(1,23)=-2.3$, $p=.032$ and $t(1,23)=2.1, p=.046)$. In both cases, the effect size was average: $d$-Cohen $=.43$ and $d$-Cohen $=.46$, respectively. This result is interesting and requires independent verification since we used the same data set for two different types of statistical analysis.

\section{Discussion}

The main result of our work is that matching the color and meaning of the word causes a decrease in response time, even if the response does not match the meaning of the word. Thus, a response conflict does not occur without a semantic conflict. It can be thought of as if the color and meaning of a word are combined into one representation, and then this representation is "translated" into another one according to the rules of response production. However, combining the representation of color and meaning is possible only after processing both the font color and meaning of the word. But if the color of a word is already identified, then the meaning of a word is no longer necessary for effective task performance. Moreover, in this case, the word meaning does not match the correct response, and its "translation" into the correct response takes time. For this reason, congruence at the semantic level in itself should not speed up the response time.

To explain the obtained results, let us consider the mechanisms that allow a correct response to the Stroop task despite conflicts. Those mechanisms usually are related to cognitive control (Botvinick, Braver, Barch, Carter, \& Cohen, 2001; see also Schmidt, 2019 for a critical review). The general belief is that control weakens the tendency to respond to the meaning of the word and increases the tendency to respond to the font color. However, a question remains how cognitive control "knows" which one of the response trends it should support. In the model proposed by Verguts and Notebaert $(2008,2009)$, conflict detection occurs before the response is ready. Moreover, conflict detection does not contain an indication of which of the processes is "erroneous," but signals the conflict "in general." In other words, conflict detection occurs at the semantic level.

To summarize, there is a monitoring mechanism that is triggered when it detects a semantic conflict. There is also a response control mechanism that works with prepared responses. If a conflict is detected on the semantic level, the prepared responses are controlled, which requires more time. After activation of the response control mechanism, task performance slows down, and the more reasons there are to reject a particular response, the sooner the final response is given. We hypothesize that this is why, in our study, when the color of a word matches its meaning, the detection mechanism was not triggered. Responses were given faster despite the incongruence at the response level. In turn, a conflict is detected when the color and meaning do not match, even if the word matches the correct response. Indeed, the conflict detection mechanism only takes the meanings of words and does not determine whether a word's meaning will match the right response. After a semantic conflict is detected, the response control is triggered. If, in reality, there is no conflict of response (e.g., "response-congruent" stimulus), the time of this control is reduced.

It should be noted that such an interpretation does not directly imply any conclusions about how exactly the responses are controlled. For now, we can only suggest that more time is spent on answering when there is a detected conflict. According to Vergats and Notebaert $(2008,2009)$ the activation of all representations in the mind increases, including the representations of the color and the meaning of the word. Nevertheless, alternative explanations can be offered: after a conflict is detected, the requirements for accuracy of the answer increase, and impulsive responses are suppressed, etc. (similar mechanisms for the Stroop task were discussed in the works of Servant, Montagnini, \& Burle, 2014 and Dhooge \& Hartsuiker, 2011).

Our results allow us to offer a solution for one of the contradictions in the study of interference. On the one hand, word meaning processing is referred to as ballistic processes. Once these mental processes are started, there is no possibility to interrupt or attenuate them (including by cognitive control mechanisms) (see Tzelgov, 1997). On the other hand, the amount of interference may decrease when the context changes (e.g., when the number of incongruent stimuli increases compared to neutral stimuli), which is cited as evidence of non-ballistic word processing (e.g., Besner 2001). The results of our research suggest that word processing on a semantic level is "ballistic," but semantic processing in its turn can trigger response control mechanisms.

\section{Conclusion}

Our research shows that semantic conflict and response conflict are not independent of each other in the Stroop test. We believe that the semantic conflict triggers control processes, but this control itself works with the responses, suppressing irrelevant answers if necessary.

\section{References}

Arbekova, O.A., \& Gusev, A.N. (2017). [About matching concepts of meaningful set, task set, and operation set with modern English-language terms]. Russian Journal of Cognitive Science, 4(1), 5-25. (In Russian). Retrieved from http:// www.cogjournal.ru/4/1/pdf/ArbekovaGusevRJCS2017.pdf.

Augustinova, M., Parris, B. A., \& Ferrand, L. (2019). The loci of Stroop interference and facilitation effects with manual and vocal responses. Frontiers in Psychology, 10, 1786:1-14. doi:10.3389/fpsyg.2019.01786

Bekçi, B., \& Karakaş, S. (2009). Perceptual conflict and response competition: Event-related potentials of the Stroop effect. Türk Psikiyatri Dergisi, 20(2), 127-137. (In Turkish). Retrieved from http://www.turkpsikiyatri.com/PDF/ C20S2/127-137.pdf. 
Besner, D. (2001). The myth of ballistic processing: Evidence from Stroop's paradigm. Psychonomic Bulletin and Review, 8(2), 324-330. doi:10.3758/bf03196168

Botvinick, M.M., $\quad$ Braver, T.S., $\quad$ Barch, D. M., $\quad$ Carter, C.S. \& Cohen, J.D. (2001). Conflict monitoring and cognitive control. Psychological Review, 108(3), 624-652. doi:10.1037/0033-295x.108.3.624

Brown, T.L., Roos-Gilbert, L., \& Carr, T.H. (1995). Automaticity and word perception: Evidence from Stroop and Stroop dilution effects. Journal of Experimental Psychology: Learning, Memory, and Cognition, 21(6), 1395-1411. doi: $10.1037 / 0278-7393.21 .6 .1395$

Dhooge, E., \& Hartsuiker, R. J. (2011). How do speakers resist distraction? Psychological Science, 22(7), 855-859. doi:10.1177/0956797611410984

Doehrman, S., Landau, R., \& O'Connell, D. (1978). The Stroop phenomenon: Perceptual conflict or response competition? Perceptual and Motor Skills, 47(3 suppl), 1127-1131. doi:10.2466/pms.1978.47.3f.1127

Durgin, F. H. (2000). The reverse Stroop effect. Psychonomic Bulletin and Review, 7(1), 121-125. doi:10.3758/bf03210730

Dyer, F. N., \& Severance, L. J. (1973). Stroop interference with successive presentations of separate incongruent words and colors. Journal of Experimental Psychology, 98(2), 438-439. doi: $10.1037 / \mathrm{h} 0034353$

Glaser, M.O., \& Glaser, W.R. (1982). Time course analysis of the Stroop phenomenon. Journal of Experimental Psychology: Human Perception and Performance, 8(6), 875-894. doi:10.1037/0096-1523.8.6.875

Harrison, N. S., \& Boese, E. (1976). The locus of semantic interference in the "Stroop" color-naming task. Perception and Psychophysics, 20(5), 408-412. doi:10.3758/bf03199423

Hasshim, N., \& Parris, B.A. (2015). Assessing stimulus-stimulus (semantic) conflict in the Stroop task using saccadic twoto-one color response mapping and preresponse pupillary measures. Attention, Perception, \& Psychophysics, 77(8), 2601-2610. doi:10.3758/s13414-015-0971-9

Janssen, N., Schirm, W., Mahon, B.Z., \& Caramazza, A. (2008). Semantic interference in a delayed naming task: Evidence for the response exclusion hypothesis. Journal of Experimental Psychology: Learning, Memory, and Cognition, 34(1), 249-256. doi:10.1037/0278-7393.34.1.249

Kalanthroff, E., $\quad$ Davelaar, E. J., Henik, A., Goldfarb, L. \& Usher, M. (2018). Task conflict and proactive control: A computational theory of the Stroop task. Psychological Review, 125(1), 59-82. doi:10.1037/rev0000083

Kinoshita, S., de Wit, B., Aji, M., \& Norris, D. (2017). Evidence accumulation in the integrated and primed Stroop tasks. Memory and Cognition, 45(5), 824-836. doi:10.3758/ s13421-017-0701-8

Luo, C.R. (1999). Semantic competition as the basis of Stroop interference: Evidence from color-word matching tasks. Psychological Science, 10(1), 35-40. doi:10.1111/ 1467-9280.00103

Lupker, S. J., \& Katz, A. N. (1981). Input, decision, and response factors in picture-word interference. Journal of Experimental Psychology: Human Learning and Memory, 7(4), 269-282. doi:10.1037/0278-7393.7.4.269

Mills, L., Kinoshita, S., \& Norris, D. (2019). No negative priming effect in the manual Stroop task. Frontiers in Psychology, 10, 1764:1-9. doi:10.3389/fpsyg. 2019.01764

Parris, B. A. (2014). Task conflict in the Stroop task: When Stroop interference decreases as Stroop facilitation increases in a low task conflict context. Frontiers in Psychology, 5, 1182:1-9. doi:10.3389/fpsyg.2014.01182

Parris, B. A., Wadsley, M.G., Hasshim, N., Benattayallah, A., Augustinova, M., \& Ferrand, L. (2019). An fMRI study of response and semantic conflict in the Stroop task. Frontier in Psychology, 10, 2426:1-12. doi:10.3389/fpsyg.2019.02426

Riley, E., McMahon, K. L., \& de Zubicaray, G. (2015). Long-lasting semantic interference effects in object naming are not necessarily conceptually mediated. Frontiers in Psychology, 6 , 578:1-14. doi:10.3389/fpsyg. 2015.00578

Schmidt, J.R. (2018). Evidence against conflict monitoring and adaptation: An updated review. Psychonomic Bulletin and Review, 26(3), 753-771. doi:10.3758/s13423-018-1520-Z

Schmidt, J. R., Cheesman, J., \& Besner, D. (2013). You can’t Stroop a lexical decision: Is semantic processing fundamentally facilitative? Canadian Journal of Experimental Psychology / Revue canadienne de psychologie expérimentale, 67(2), 130-139. doi:10.1037/a0030355

Schmidt, J. R., Hartsuiker, R. J., \& Houwer, J.D. (2018). Interference in Dutch-French bilinguals. Experimental Psychology, 65(1), 13-22. doi:10.1027/1618-3169/a000384

Servant, M., Montagnini, A., \& Burle, B. (2014). Conflict tasks and the diffusion framework: Insight in model constraints based on psychological laws. Cognitive Psychology, 72, 162-195. doi:10.1016/j.cogpsych.2014.03.002

Sharma, D., \& McKenna, F.P. (1998). Differential components of the manual and vocal Stroop tasks. Memory and Cognition, 26(5), 1033-1040. doi:10.3758/bf03201181

Shichel, I., \& Tzelgov, J. (2018). Modulation of conflicts in the Stroop effect. Acta Psychologica, 189, 93-102. doi:10.1016/j. actpsy.2017.10.007

Stafford, T., \& Gurney, K. N. (2011). Additive factors do not imply discrete processing stages: A worked example using models of the Stroop task. Frontiers in Psychology, 2, 287:1-9. doi:10.3389/fpsyg.2011.00287

Starreveld, P. A., \& Heij, W.L. (2016). Picture-word interference is a Stroop effect: A theoretical analysis and new empirical findings. Psychonomic Bulletin and Review, 24(3), 721-733. doi:10.3758/s13423-016-1167-6

Steinhauser, M., \& Hübner, R. (2009). Distinguishing response conflict and task conflict in the Stroop task: Evidence from ex-Gaussian distribution analysis. Journal of Experimental Psychology: Human Perception and Performance, 35(5), 1398-1412. doi:10.1037/a0016467

Stroop, J.R. (1935). Studies of interference in serial verbal reactions. Journal of Experimental Psychology, 18(6), 643-662. doi:10.1037/h0054651

Tzelgov, J. (1997). Automatic but conscious: That is how we act most of the time. In R.S. Wyer, \& T.K. Srull (Eds.), The Automaticity of Everyday Life. Advances in social cognition, (vol. 10. pp. 217-230). Urbana-Champaign: University of Illinois.

Utochkin, I.S., \& Bolshakova, K.G. (2010). Strengthening and reduce of the Stroop effect in probabilistic learning. Psychology. Journal of Higher School of Economics, 7(3), 139-149. (In Russian).

van Veen, V., \& Carter, C.S. (2005). Separating semantic conflict and response conflict in the Stroop task: A functional MRI study. NeuroImage, 27(3), 497-504. doi:10.1016/j. neuroimage.2005.04.042

Verguts T., \& Notebaert, W. (2008). Hebbian learning of cognitive control: Dealing with specific and nonspecific adaptation. Psychological Review, 115(2), 518-525. doi: 10.1037/0033-295X.115.2.518

Verguts, T., \& Notebaert, W. (2009). Adaptation by binding: a learning account of cognitive control. Trends in Cognitive Sciences, 13(6), 252-257. doi:10.1016/j.tics.2009.02.007

Wadsley, M. (2019). An fMRI and TMS investigation of response, semantic, and task conflict in the Stroop task. Unpublished doctoral dissertation, Bournemouth University. Retrieved from http://eprints.bournemouth.ac.uk/31760/1/ WADSLEY\%2C\%20Michael M.Res. 2018.pdf.

Wendelken, C., Ditterich, J., Bunge, S. A., \& Carter, C. S. (2009). Stimulus and response conflict processing during perceptual decision making. Cognitive, Affective, and Behavioral Neuroscience, 9(4), 434-447. doi:10.3758/cabn.9.4.434 


\title{
Роль конфликта ответов \\ и семантического
}

\section{конфликта в возникновении эффекта Струпа}

\section{Алексей Сергеевич Стародубцев}

Факультет психологии, Санкт-Петербургский государственный университет, Санкт-Петербург, Россия

\section{Михаил Викторович Аллахвердов}

Факультет свободных искусств и наук, Санкт-Петербургский государственный университет, Санкт-Петербург, Россия

\begin{abstract}
Аннотация. Эффект Струпа чаще всего объясняют семантическим конфликтом или конфликтом ответов. В литературе описано несколько способов разграничить эти конфликты: использовать слова не из набора ответов, использовать методический прием 2:1 (один ответ на два типа стимулов), использовать ассоциативно связанные цвета и слова. Однако мы считаем, что эти способы не могут полностью разграничить семантический конфликт и конфликт ответов. Мы попробовали разграничить эти конфликты при помощи другой методики. При выполнении теста Струпа (задача: называть цвета окрашенных слов - например, красный, желтый и т. д.) вместо названий некоторых из цветов испытуемые должны были называть другие цвета (например, стимулы красного цвета требовалось называть словом «желтый»). Этот метод позволил создать семантически конгруэнтные стимулы, но конфликтные относительно ответов (слово «красный» написано красным шрифтом, но испытуемые должны сказать «желтый»). Также были созданы конгруэнтные относительно ответов, но семантически конфликтные стимулы (слово «желтый» написано красным цветом, и испытуемые должны сказать «желтый» из-за указанного правила). Было обнаружено, что эффект Струпа не возникает при семантической конгруэнтности, даже если значение слова является неправильным ответом. В свою очередь, конгруэнтность относительно ответов снижает интерференционный эффект, но все равно оставляет его значимым. Таким образом, конфликт ответов влияет на величину эффекта Струпа только при наличии семантического конфликта. Полученные данные не соответствуют моделям, предполагающим прямую активацию ответов, соответствующих значениям слов.
\end{abstract}

Контактная информация: Алексей Сергеевич Стародубцев, fleksbr@yandex.ru, 199034, Санкт-Петербург, Университетская наб., 7/9, СПбГУ; Михаил Викторович Аллахвердов, m.allakhverdov@smolny.org.

Ключевые слова: тест Струпа, интерференция, семантический конфликт, конфликт ответов, внимание

( 2019 Алексей Сергеевич Стародубцев, Михаил Викторович Аллахвердов. Данная статья доступна по лицензии Creative Commons "Attribution” («Атрибуция») 4.0. всемирная, согласно которой возможно неограниченное распространение и воспроизведение этой статьи на любых носителях при условии указания авторов и ссылки на исходную публикацию статьи в данном журнале в соответствии с канонами научного цитирования.

Благодарности. Исследование выполнено при поддержке РФФИ (номер проекта 18-013-01212).

Статья частично основана на материалах более ранней публикации в сборнике конференции: Стародубиев А.С. Роль конфликта ответов и семантического конфликта в возникновении эффекта Струпа // Когнитивная наука в Москве: новые исследования. Материалы конференции 19 июня 2019 г. / Под ред. Е. В. Печенковой, М. В. Фаликман. М.: Буки Веди, ИППиП. С. 490-495.

Статья поступила в редакцию 30 сентября 2019 г. Принята в печать 27 декабря 2019 г. 


\section{Введение}

Классический эффект Струпа (интерференция) заключается в задержке называния цвета слова, которое обозначает другой цвет (цвет слова не совпадает со значением; Stroop, 1935). Такие стимулы называются неконгруэнтными (слово «красный», написанное синим цветом). Временную задержку считают относительно времени называния цвета нечитаемых знаков (например, XXXXXX). Киношита с соавторами заметили: «Все согласны, что между словом и значением происходит конфликт, но непонятно, какова природа этого конфликта» ${ }^{\mathbf{1}}$ (Kinoshita et al., 2017, p. 824). Слово характеризуется множеством параметров, каждый из которых может влиять на эффект интерференции: сам факт наличия слова, принадлежность слова к категории «цвета», ассоциативная связь значения слова и его цвета, совпадение значения слова с правильным ответом предыдущих проб и т. д. (Sharma, McKenna, 1998).

Конфликт между цветом слова и его значением может происходить на разных стадиях обработки информации. На ранних стадиях обработки информации анализируются физические признаки стимула, затем происходит его семантическая обработка, и на самых поздних стадиях готовится ответ на стимул. Соответственно, выделяются три вида конфликтных ситуаций, которые влияют на скорость и точность выполнения задания: конфликт задач, семантический конфликт, конфликт ответов. Конфликт задач (task conflict) отражает влияние самого факта прочтения слова. Так как операция чтения не относится к задаче, ее выполнение вступает в конфликт с задачей называния цвета. Тем не менее фактор конфликта задач слабее влияет на скорость ответов по сравнению с семантическим конфликтом или конфликтом ответов (Lupker, Katz, 1981). Считается, что влияние конфликта задач можно обнаружить только в специфических условиях (см. Parris, 2014). Калантрофф с соавторами заключают, что в условиях, когда контрольных стимулов не слишком много (меньше половины - то есть в большинстве экспериментов), конфликт задач «не происходит или быстро разрешается» (Kalanthroff et al., 2018, p. 1).

Семантический конфликт отражает влияние конфликта между образами, которые соответствуют значению слова и его цвету. На этом этапе обработки информации уже завершилось распознание цвета слова и его значения, но еще не сформировались соответствующие ответы. Конфликт на этом этапе обработки информации обозначается тем или иным образом в зависимости от понимания исследователями механизмов интерференции. Например, если интерференцию рассматривают в связи с обработкой слова, то конфликт называют «лексическим» (более ранний этап в этом случае именуется «долексическим», а более поздний - «постлексическим»; см., например, Brown et al., 1995). Если предполагается, что принимается решение о «переводе» характеристик стимулов в соответствующие реакции, то этап называется «конфликтом на

\footnotetext{
1 Англ.: "It is widely agreed that the Stroop effect reflects conflict between the colour and the to-be-ignored word, but much is still not known about the nature of that conflict" (Kinoshita et al., 2017, p. 284).
}

уровне принятия решения» (Sharma, McKenna, 1998), или просто словом «решение» в кавычках (Stafford, Gurney, 2011). Похожие представления подразумеваются также при использовании терминов «перцептивный конфликт» (Bekci, Karakas, 2009; Doehrman et al., 1978) или «конфликт стимулов» (Wendelken et al., 2009). Авторы могут по-разному понимать обработку информации на этом этапе и порой не разграничивают семантический конфликт и конфликт задач (например, Steinhauser, Hubner, 2009). Однако семантический конфликт и конфликт ответов обычно разграничивают.

Конфликт ответов традиционно рассматривался как главный фактор интерференции (Lupker, Katz, 1981; Dyer, Severance, 1973). Основные допущения гипотезы конфликта ответов таковы: человек не может одновременно назвать и цвет и значение слова, у значения слова есть приоритет в обработке по сравнению с обработкой его цвета (так как значение слова быстрее читается или автоматически обрабатывается, в отличие от цвета слова). Существуют и современные модели, в которых интерференцию объясняют тем, что подавление нерелевантного ответа требует времени (см. Janssen et al., 2008).

Тем не менее существуют и гипотезы о семантическом конфликте как основной причине интерференции (Luo, 1999). Подавляющее большинство ученых признают существование и семантического конфликта, и конфликта ответов. Во многом такая разница в позициях обусловлена разными методами разделения семантического конфликта и конфликта ответов. Рассмотрим способы, при помощи которых в экспериментах разграничивают влияние конфликта ответов и семантического конфликта.

\section{Способы разграничения семантического конфликта и конфликта ответов}

Методики, при помощи которых вызывают только семантический конфликт без конфликта ответов, используют различные способы, не дающие испытуемому совершить ошибочный ответ в соответствии со значением слова. Паррис с соавторами (Parris et al., 2019) описали основные способы разграничить влияние этих конфликтов в эксперименте, которые принимаются большинством современных авторов: использовать слова не из набора ответов, использовать семантически связанные слова и цвета, использовать кнопку ответа, которая соответствует и цвету неконгруэнтного слова, и его значению.

Первый способ - использовать слова, не входящие в набор ответов. Например, если стимулы могут быть только красного и синего цветов, то набор ответов для задачи называния цвета состоит из элементов «красный» и «синий». Показано, что значения слов не из набора ответов (в описанном выше случае: «зеленый» в синем цвете) всё равно вызывают интерференционный эффект, хотя и значимо меньший по сравнению со словами из набора ответов («красный» в синем цвете; например, Wadsley, 2019; Sharma, McKenna, 1998).

Второй способ разграничить в эксперименте влияние семантического конфликта и конфликта ответов использовать слова, ассоциативно связанные с правильными ответами. Например, человек медленнее 
называет цвет слова «вода», окрашенного в красный цвет, чем слова «вода», окрашенного в синий цвет. Так как связь значения слова «вода» и цвета его шрифта не имеет прямого отношения к ответам, то в случае предъявления слова «вода» в красном цвете предполагается только семантический конфликт (например, Augustinova et al., 2019; Harrison, Boese, 1976).

Наконец, третий способ вызвать семантический конфликт без конфликта ответов - использовать задачи, в которых надо отвечать одинаковым образом на два разных типа стимулов (методический примем 2:1). Испытуемых могут просить дать один ответ (например, нажать кнопку), если стимул будет или красным или синим. В этом случае слово «красный» в синем цвете будет семантически конфликтным, но и цвет и значение соответствуют одному ответу, и поэтому этот стимул будет конгруэнтным на уровне ответов (например, Schmidt et al., 2018; Shichel, Tzelgov, 2018; Hasshim, Parris, 2015; Steinhauser, Hubner, 2009).

\section{Критика традиционных способов разделить влияние конфликта ответов и семантического конфликта}

Описанные способы разграничить разные виды конфликтов основываются на допущениях, которые могут быть ложными. Например, действительно ли значения слов, не входящих в набор ответов, не обрабатываются на уровне ответов? Возможна и интерпретация, согласно которой конфликт ответов у значений слов не из набора ответов просто «слабее», но не на нулевом уровне. Во всяком случае, существует традиция объяснять конфликтом ответов и результаты экспериментов, в которых используются только слова не из набора ответов (например, Janssen et al., 2008). Возможна и другая линия критики: набор ответов задает физические признаки стимулов, на которые человек обращает внимание. Если человек отвечает только «красный» или «синий», то он будет обращать внимание на слова, похожие на ответы. Набор ответов может задавать в том числе и семантическую обработку стимула. Известно, например, что ожидание стимула влияет на эффективность его последующего распознавания (эффект перцептивной установки). По аналогии, набор ответов может влиять и на семантическую обработку значений слов.

Эффект ассоциативной связи между цветом слова и его значением также может включать в себя и конфликт на уровне ответов. Например, предъявление слова «трава» ускорит последующий ответ «зеленый». Соответственно, слово «вода» может подготавливать ответ «синий». Поэтому при предъявлении слова «вода» в красном цвете возможен конфликт ответов между ответами «красный» и «синий», то есть ослабленный конфликт ответов. Шмидт и коллеги (Schmidt et al., 2013) показали, что эффект «ассоциативного конфликта» (слово «трава» в красном цвете) наблюдается только тогда, когда слово «зеленый» входит в набор ответов. По мысли авторов, именно ответ «зеленый» конкурирует со словом «красный» в случае предъявления слова «трава» в красном цвете, но не происходит семантического конфликта между словом «трава» и словом «красный». В самом деле, Шмидт и коллеги показа- ли, что в отличных от задачи Струпа методиках (задачи чтения слов, лексического решения) слово «красный» ускоряет последующую обработку слова «трава». По этой причине нельзя исключать и влияние конфликта ответов в случае семантической связи значения слова и его цвета. В работе Рилей с соавторами (Riley et al., 2015) в методике «рисунок-слово»² было показано, что ознакомление в эксперименте с возможными ответами влияет на эффект «семантической интерференции». Это еще больше усложняет возможные методы разграничения семантического конфликта и конфликта ответов.

Использование методического приема 2:1 выглядит самым надежным способом вызвать семантический конфликт без конфликта ответов. Однако в известных нам экспериментах прием 2:1 использовали только в двигательных (моторных) вариантах задачи Струпа. В них испытуемые должны были не называть вслух цвета, а сделать определенное движение рукой или глазом, которое перед экспериментом было обозначено как "соответствующее некоторому цвету». В исследовании Хашшима и Парриса (Hasshim, Parris, 2015) испытуемые давали ответ при помощи перевода взгляда: к примеру, если стимул был синий или зеленый, то требовалось посмотреть на один квадрат, если красный или желтый - то на другой. В исследовании ван Вина и Картера (van Veen, Carter, 2005) испытуемые должны были нажимать на кнопки: например, на одну кнопку, если стимул был зеленым или синим, и на другую - если стимул был красным или желтым. В этой задаче слово «зеленый» в синем цвете являлось семантически конфликтным, но конгруэнтным на уровне ответов (значение слова и его цвет соответствуют одному ответу). Конгруэнтности на уровне ответов оказалось достаточно для значимого снижения или нивелирования эффекта Струпа.

Тем не менее моторный вариант задачи Струпа значительно отличается от задачи называть цвет слова вслух. В задаче называния вслух обнаружен приоритет в обработке значения слов. Значения слов влияют на скорость называния цвета, а цвет слов не оказывает влияния на скорость чтения (асимметричность эффекта Струпа; Glaser, Glaser, 1982). Однако это не так в моторных вариантах задачи Струпа. Испытуемые медленнее отвечают на значение слова, когда оно не совпадет с цветом его шрифта, если для ответа используются клавиши или компьютерная мышь (обратный эффект Струпа; Durgin, 2000).

Известный факт - испытуемые быстрее сопоставляют цвет окрашенного прямоугольника с цветом слова, а не с его значением (например, Luo, 1999). Подобные факты часто служат для критики гипотезы о конфликте ответов. Ведь если слово действительно получает приоритет в обработке, то испытуемые должны быстрее сличать значение слова с цветом прямоугольника, а не цвет слова с цветом прямоугольника. Подобная критика может вызвать удивление, так как в данном случае используется задача, которая

\footnotetext{
2 В этой методике испытуемые на скорость называют изображения и игнорируют наложенные поверх них слова. Методика рисунокслово считается одним из самых близких аналогов классической методики Струпа (см. Starreveld, La Heij, 2017).
} 
значительно отличается от классической задачи Струпа. На наш взгляд, использование неклассических методик должно быть обосновано или логически, или результатами экспериментов. Однако даже использование моторного варианта задачи Струпа не удовлетворяет этому требованию. Например, при прохождении голосовой версии теста Струпа возникает эффект негативного прайминга: испытуемые медленнее называют цвет слова, если он совпадает со значением предыдущего слова. Этот феномен может быть интерпретирован через гипотезу о конфликте ответов: подавление ответа, соответствующего значению слова, распространяется и на обработку следующего стимула, в котором этот ответ уже является правильным решением задачи. Однако в моторном варианте теста Струпа эффекта негативного прайминга не обнаружено (Mills et al., 2019). Более того, на разницу между моторным и голосовым вариантами задачи Струпа указывает исследование Шармы и Макенны (Sharma, McKenna, 1998). В этой работе предъявлялись различные стимулы, которые содержали несколько факторов интерференции: лексический фактор, фактор семантической связи, фактор лексической связи, фактор принадлежности к набору ответов. Окрашенный набор букв не содержит ни одного из этих факторов; слова, не имеющие прямого отношения к цветам (стол, гвоздь), содержат только лексический фактор; слова, связанные с цветом (море, трава), содержат фактор лексической связи; цветные слова не из набора ответов (оранжевый, белый) содержат фактор лексической релевантности; а классические неконгруэнтные слова содержат все описанные факторы. Каждый из факторов увеличивал интерференцию в голосовом варианте задачи Струпа, но на величину интерференции в моторном варианте методики Струпа значимо влиял только фактор принадлежности к набору ответов. Это говорит о том, что голосовой и моторный варианты теста Струпа нельзя использовать как взаимозаменяемые методики, по крайней мере при изучении роли семантического конфликта и конфликта ответов.

\section{Обоснование исследования}

Таким образом, чаще всего семантический конфликт и конфликт ответов разграничивали либо при помощи варьирования набора ответов или ассоциативной связи, либо - методического приема 2:1. Варьирование набора ответов и ассоциативной связи допускает интерпретацию и конфликта на уровне ответов, а методический прием 2:1 использовался только в моторных вариантах задачи Струпа. По этим причинам наша первая цель - воспроизвести методический прием 2:1 на материале голосовой задачи Струпа.

Другая причина проведения исследований касается слишком громоздкого описания разных видов конфликтов в современных работах по интерференции в задачи Струпа. Мы считаем, что существование многих видов конфликтов (и многих видов «контролей» этих конфликтов) избыточно с логической точки зрения. Например, если для правильного выполнения задания требуется разрешить семантический конфликт, то конфликта ответов уже быть не должно. Если же значение слова подавляется на уровне ответов, то нет необходимости подавлять его и на семантическом уровне.

\section{План исследования}

В нашем исследовании мы планировали «в чистом виде» вызвать конфликт на уровне ответов или на семантическом уровне с использованием голосовой задачи Струпа. Испытуемые проходили голосовой вариант задачи Струпа, но два цвета они должны были называть другими словами, обозначающими цвета (идея этой методики была высказана в статье Арбековой и Гусева, 2017). Например, в ответ на стимулы красного цвета следовало говорить «желтый». Рассмотрим интересующие нас экспериментальные условия, которые были реализованы в описанной методике. Допустим, предъявляется слово «красный» в красном цвете, когда испытуемые должны называть красные по цвету стимулы словом «желтый». С одной стороны, значение слова не активизирует правильный для задачи ответ. С другой стороны, на семантическом уровне существует больше источников информации, связанных с образом «красный». Избыточность информации иногда позволяет отвечать быстрее (Уточкин, Большакова, 2010).

Другое интересующее нас условие - совпадение значения слова с правильным ответом при семантическом конфликте. Например, предъявлено слово «красный» в желтом цвете, когда испытуемому дана инструкция отвечать «красный» в ответ на стимулы желтого цвета. Цвет не совпадает со значением (семантический конфликт), однако значение слова совпадает с ответом, который испытуемые должны дать. Мы предполагаем, что такой дизайн позволит разграничить конфликт на уровне ответов и семантический конфликт.

Предложенный эксперимент предполагает не только условие «семантический конфликт без конфликта ответов», но и условие «конфликт ответов без семантического конфликта». Таким образом, основная задача исследования - выяснить, являются ли факторы «конфликта ответов» и «семантического конфликта» независимыми друг от друга. Примеры стимулов, которые реализуются в методике, представлены в таблице 1.

\section{Эксперимент}

\section{Методы}

Выборка. В исследовании приняло участие 24 человека в возрасте от 18 до 40 лет - $\mathrm{M}=24.4 ; S D=5.8$ (7 мужчин и 17 женщин). Испытуемые участвовали в эксперименте в рамках мероприятия «Неделя экспериментов». Респонденты не получали вознаграждения за участие в исследовании.

Оборудование и программное обеспечение. Стимулы предъявлялись на LCD-дисплее стационарного компьютера с шумоподавляющим микрофоном, расстояние от глаз испытуемого до экрана дисплея составляло 50-60 см. Характеристики монитора: диагональ 24 (61 см); ширина экрана: 53 см; высота экрана: 29.5 см; разрешение: $1920 \times 1080$ (16:9); частота обновления экрана: 60 Гц (максимум 144 Гц). Предъявление 
Таблица 1. Пример экспериментальных условий для правила “стимулы синего цвета надо назвать словом „красный“, стимулы красного и зеленого цвета надо называть привычным образом»

\begin{tabular}{|c|c|c|c|c|c|}
\hline \multirow{2}{*}{$\begin{array}{l}\text { Пример } \\
\text { стимула }\end{array}$} & \multirow{2}{*}{$\begin{array}{l}\text { Правильный } \\
\text { ответ }\end{array}$} & \multicolumn{2}{|c|}{ Формальные характеристики стимула } & \multirow{2}{*}{$\begin{array}{l}\text { Совпадение цвета } \\
\text { слова и значения }\end{array}$} & \multirow{2}{*}{$\begin{array}{l}\text { Совпадение значения слова } \\
\text { и правильного ответа }\end{array}$} \\
\hline & & Конгруэнтность & Тип наименования & & \\
\hline КРАСНЫЙ & «красный» & конгруэнтный & тот же цвет & ДА & ДА \\
\hline СИНИЙ & «красный» & конгруэнтный & иной цвет & ДА & HET \\
\hline$X X X X X X$ & «красный» & нейтральный & тот же цвет & - & - \\
\hline$X X X X X X$ & «красный» & нейтральный & иной цвет & - & - \\
\hline СИНИЙ & «зеленый» & неконгруэнтный & тот же цвет & HET & HET \\
\hline ЖЕЛТЫЙ & «красный» & неконгруэнтный & иной цвет & HET & HET \\
\hline КРАСНЫЙ & «красный» & неконгруэнтный & иной цвет & HET & ДА \\
\hline
\end{tabular}

стимулов и запись ответов осуществлялись при помощи программы PsychoPy2. Временной промежуток между появлением стимула и началом ответа, а также правильность вокализации считались вручную в программе Praat.

Стимулы. Нейтральные стимулы: знаки «XXXXXX», окрашенные в синий, зеленый, красный или желтый цвета. Конгруэнтные стимулы: слова «красный», «синий», «желтый» и «зеленый», напечатанные цветом, совпадающим с их значением. Неконгруэнтные стимулы: слова, цвет которых не совпадает с их значением; использовались слова «красный», «синий», «желтый» и «зеленый» и соответствующие цвета. Каждое сочетание цвет-значение для условия «неконгруэнтные стимулы» повторялось равное число раз.

Существовало 12 правил называния цветов. Например, одно из правил: в ответ на стимулы красного цвета называть слово «синий», в ответ на стимулы желтого называть слово «зеленый». Каждый испытуемый получал одно из 12 правил.

Процедура. Перед экспериментом при помощи метода латинского квадрата каждому испытуемому назначалось правило произнесения цветов слов. Два цвета испытуемые должны были произносить привычным образом, а два других - другими цветами (например, вместо «зеленый» говорить «синий», а вместо «красный» - «желтый»). На тренировочных этапах испытуемых инструктировали отвечать как можно точнее, не обращая внимания на скорость. На экспериментальном этапе уже ставилась задача отвечать как можно быстрее. Однако испытуемых предупреждали, что любые запинки, посторонние звуки («ааа», «ммм» и т.д.) и растягивания слов («сссиний») будут расцениваться как ошибки.

Два начальных этапа предназначались для тренировки непривычного называния. На первом этапе испытуемые произносили цвета 60 нейтральных стимулов (четыре варианта цветов). На втором тренировочном этапе было 36 стимулов, которые уже могли быть нейтральными, неконгруэнтными или конгруэнтными. Стимулы предъявлялись по одному на сером фоне; стимулы были написаны шрифтом Arial в верхнем регистре (в среднем -8 см в ширину и $1 \mathrm{~cm}$ в высоту).
На первых двух этапах для запуска следующей пробы испытуемые должны были нажать пробел, экспериментатор сидел рядом и при необходимости напоминал правило или обращал внимание испытуемых на их ошибки. На третьем этапе испытуемые уже должны были выполнять работу самостоятельно: на 1000 мс предъявлялся пустой экран, затем на 300 мс - фиксационный крест, затем на 400 мс - пустой экран и, наконец, на 1700 мс - Струп-стимул. После отведенного времени начиналась следующая проба вне зависимости от того, успел испытуемый дать ответ или нет. Всего было 144 стимула, треть из которых были конгруэнтными, треть - неконгруэнтными и оставшиеся - нейтральными (фактор: тип стимулов); в половине случаев от испытуемых требовалось называть цвета слов, в половине - в ответ на определенные цвета называть другие цвета (фактор: тип наименования). Порядок предъявления стимулов был случайным, но не допускалось повторения цвета, значения, фактора конгруэнтности более трех раз подряд, фактора типа называния - более пяти раз подряд.

\section{Результаты}

В случае полного или частичного называния неверного ответа или наличия посторонних вокализаций («М-м-м», «э-э-э» и т.д.) ответ считался ошибочным. Все ошибочные ответы были удалены из анализа: $3.5 \%$ для конгруэнтных стимулов, $8 \%$ для неконгруэнтных и $3.1 \%$ для нейтральных в случае называния тех же цветов и $1.9,6.4$ и $2.8 \%$ для тех же параметров в случае называния других цветов. Впоследствии анализировалось лишь время правильных ответов.

На рисунке 1 представлено среднее время правильных ответов в зависимости от факторов тип наименования и тип стимулов.

При анализе фактора тип стимулов тест сферичности Моучли выявил нарушения $(W=.408, p<.001)$, поэтому в дисперсионном анализе с повторными измерениями (факторы: тип стимулов и тип наименования; номер испытуемого - группирующий фактор) использовалась поправка Гринхауса - Гейсера. Влияние факторов тип стимулов (конгруэнтные, нейтральные и неконгруэнтные) и тип наименования (привычные названия, непривычные названия) оказалось 


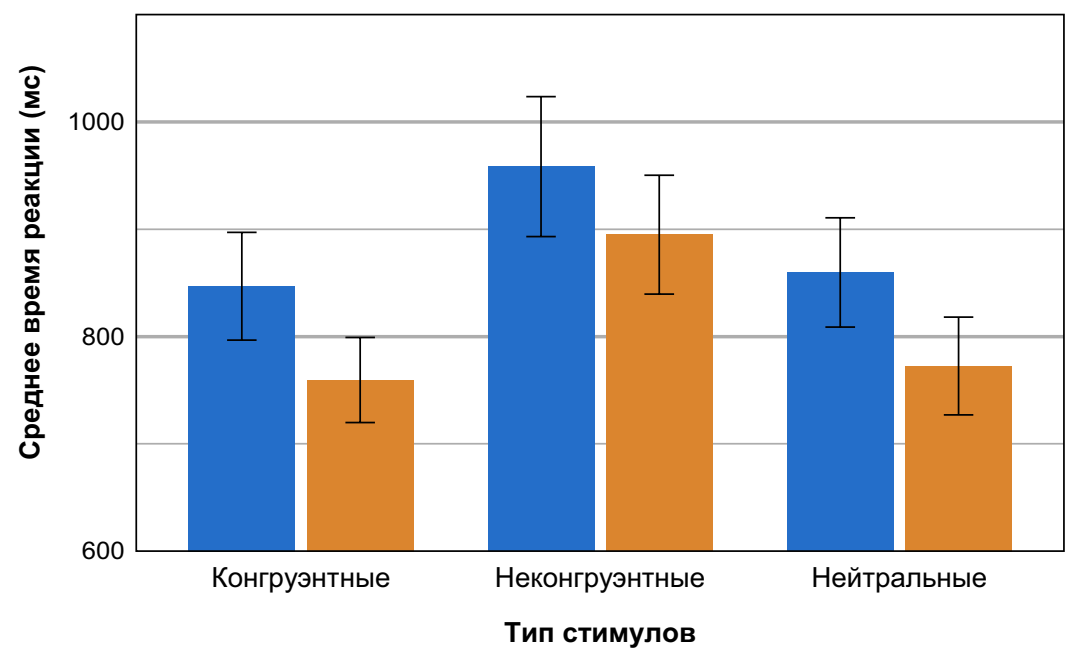

Рисунок 1. Среднее время ответов в зависимости от типа стимулов и типа наименования. Приведен $95 \%$-ный доверительный интервал

статистически значимым: $F(2,46)=69, \eta_{\mathrm{p}}^{2}=.65, p<.001$ и $F(1,23)=46, \quad \eta_{\mathrm{p}}^{2}=.70, \quad p<.001 . \quad$ Взаимодействие факторов статистически незначимо $(F(2,46)=1.25$; $\left.\eta_{\mathrm{p}}^{2}=.05, p=.29\right)$ (рисунок 1). Post-hoc-анализ мощности выявил, что все наблюдаемые эффекты обладают высокой мощностью (Observed Power $=1)$.

Испытуемые значимо медленнее давали ответы, если требовалось обозначать цвет стимулов другими названиями цветов $(M D=79 \mathrm{Mc}, S E=12)$. Posthoc-анализ фактора тun стимулов с поправками Бонферрони выявил более медленную реакцию на неконгруэнтные стимулы $(M=927$ мс; $S D=27)$ по сравнению со скоростью ответов на нейтральные $(M=816$ мс; $S D=23)$ и конгруэнтные стимулы $(M=803 \mathrm{Mc}, S D=22)$. Оба отличия статистически значимы $(M D=123 ; S E=13$; $p<.001$ и $M D=110 ; S E=17 ; p<.001)$.

В предыдущем анализе не учитывались семантически конфликтные стимулы, которые были неконгруэнтными, но были конгруэнтны относительно ответов (например, слово «красный» в желтом цвете при инструкции называть желтые объекты словом «красный»). У каждого испытуемого было по восемь таких «моторноконгруэнтных» стимулов. В нашем эксперименте мы сделали равную пропорцию стимулов каждого типа, каждого цвета и значения, так как иначе мы столкнулись бы с артефактами в виде ассоциативного научения или эффектов ожидания. Поэтому было не так много «моторноконгруэнтных» стимулов. Тем не менее мы повторно использовали часть наших данных для анализа времени ответов именно на «моторноконгруэнтные» стимулы. Время ответов на «моторноконгруэнтные» стимулы сравнивалось со временем ответов на конгруэнтные стимулы (непривычные названия) и остальные неконгруэнтные стимулы (непривычные названия, но не моторноконгруэнтные). Время ответов на «моторноконгруэнтные» стимулы в среднем меньше времени ответов на неконгруэнтные стимулы $(\mathrm{M}=908$ мс, $S D=44$ против $S D=958$ мс, $S D=32)$, но больше времени ответов на конгруэнтные стимулы $(\mathrm{M}=908$ мс, $S D=44$ против $M=848$ мс, $S D=24)$. Оба отличия статистически значимы: $t(1,23)=-2.3$, $p=.032$ и $t(1,23)=2.1, p=0.046$. В обоих случаях обнаружена средняя величина эффекта: $d$-Коэна $=.43$ и $d$-Коэна = 46 соответственно. Этот результат любопытен и требует независимой проверки, так как мы использовали один набор данных для двух разных видов статистического анализа.

\section{Обсуждение}

Ключевой результат нашей работы - совпадение цвета и значения слова вызывает уменьшение времени ответов, даже если ответ не совпадет со значением слова. Таким образом, конфликт ответов не работает без семантического конфликта. Это можно представить, как будто цвет и значение объединяются в один образ и потом этот образ «переводится» в другой в соответствии с правилами ответов. Однако объединение образов цвета и значения возможно только после обработки и образа цвета слова, и образа значения слова. Но если уже определен цвет слова, то значение слова уже не нужно для эффективного выполнения задачи. Более того, в этом случае значение слова не совпадает с правильным ответом, а его «перевод» в правильный ответ требует времени. По этой причине конгруэнтность на семантическом уровне как будто не должна ускорять время ответов.

Для объяснения полученных результатов требуется рассмотреть механизмы, позволяющие правильно отвечать при выполнении задачи Струпа, несмотря на конфликты. Часто их связывают с когнитивным контролем (Botvinick et al., 2001, см. также критический разбор Schmidt, 2018). Считается, что контроль ослабляет тенденцию к ответу на значение слова и усиливает тенденцию к ответу на цвет слова. Однако в этом случае требуется ответить на вопрос, откуда когнитивный контроль «знает», какую именно из тенденций к реагированию надо поддержать. В модели, предложенной Вергатсом и Ноутбаертом (Verguts, Notebaert, 2008, 2009), обнаружение конфликта происходит еще до формирования ответов. Причем обнаружение конфликта не содержит указания на то, какой именно из процессов «ошибочный», а сигнализирует о конфликтности «вообще». Другими словами, обнаружение конфликта происходит еще на семантическом уровне. 
Подытожим: существует механизм мониторинга, который срабатывает при обнаружении семантического конфликта, и механизм контроля ответов, который работает с подготовленными ответами. Если обнаружен конфликт на семантическом уровне, то подготовленные ответы контролируются, и на это тратится время. После включения механизма контроля ответов задача будет выполнена несколько медленнее, причем чем больше оснований отказаться от определенного ответа, тем быстрее будет дан итоговый ответ. Мы предполагаем, что именно поэтому в нашем исследовании при совпадении цвета слова и его значения механизм обнаружения неконгруэнтности не был задействован и ответы давались быстрее, несмотря на «неконгруэнтность» относительно ответов. В свою очередь, конфликт обнаруживается при несовпадении цвета и значения, даже если слово соответствует правильному ответу. В самом деле, механизм обнаружения конфликта определяет только значения слов и не определяет, будет ли значение слова соответствовать правильному ответу. После обнаружения семантического конфликта запускается контроль ответов. Если в действительности конфликта ответов не происходит (например, предъявлены «моторноконгруэнтные» стимулы), то длительность этого контроля снижается. Заметим, что из такой интерпретации прямо не следует выводов о том, как именно контролируются ответы, - ясно только, что при обнаружении конфликта тратится большее время на ответ. По мнению Вергатса и Ноутбаерта (Verguts, Notebaert, 2008, 2009), после обнаружения конфликта увеличивается активация всех образов, которые содержатся в психике, включая образ цвета слова и образ значения слова. Тем не менее можно предложить и альтернативные объяснения: после обнаружения конфликта повышаются требования к точности ответа, подавляются импульсивные ответы и т.д. (схожие механизмы применительно к Струп-интерференции обсуждались в работах Servant et al., 2014, и Dhooge, Hartsuiker, 2011).

Наши результаты позволяют предложить решение для одного из противоречий в исследовании интерференции. С одной стороны, обработку значения слов относят к баллистическим процессам (ballistic processing) - после запуска этих психических процессов нет возможности их прервать или ослабить (в том числе и со стороны механизмов когнитивного контроля) (см. Tzelgov, 1997). С другой стороны, величина интерференции может снижаться при изменении контекста (к примеру, при увеличении числа неконгруэнтных стимулов по отношению к нейтральным), что приводится как доказательство небаллистичности обработки значения слова (например, Besner, 2001). Результаты нашего исследования позволяют предположить, что обработка слова на семантическом уровне происходит «баллистично», но сама семантическая обработка может запустить механизмы контроля ответов.

\section{Вывод}

Наше исследование показывает, что семантический конфликт и конфликт ответов не являются независимыми друг от друга в тесте Струпа. Мы считаем, что се- мантический конфликт запускает процессы контроля, но сам этот контроль работает уже с ответами, при необходимости подавляя нерелевантные ответы.

\section{Литература}

Арбекова О.А., Гусев А.Н. О соотношении понятий операциональной, целевой и смысловой установки с современными англоязычными терминами // Российский журнал когнитивной науки. 2017. Т. 4. № 1. C. 5-25. URL: http://www. cogjournal.ru/4/1/pdf/ArbekovaGusevRJCS2017.pdf.

Уточкин И.С., Большакова К.Г. Усиление и ослабление эффекта Струпа при вероятностном научении // Психология. Журнал Высшей школы экономики. 2010. Т. 7. № 3. С. 139-149.

Augustinova M., Parris B. A., Ferrand L. The loci of Stroop interference and facilitation effects with manual and vocal responses // Frontiers in Psychology. 2019. Vol. 10. P. 1786:1-14. doi:10.3389/fpsyg.2019.01786

Bekçi B., Karakaş S. Perceptual conflict and response competition: Event-related potentials of the Stroop effect // Türk Psikiyatri Dergisi. 2009. Vol.20. No. 2. P. 127-137. URL: http://www. turkpsikiyatri.com/PDF/C20S2/127-137.pdf.

Besner D. The myth of ballistic processing: Evidence from Stroop's paradigm // Psychonomic Bulletin and Review. 2001. Vol. 8. No. 2. P.324-330. doi:10.3758/bf03196168

Botvinick M.M., Braver T.S., Barch D.M., Carter C.S., Cohen J.D. Conflict monitoring and cognitive control // Psychological Review. 2001. Vol.108. No.3. P.624-652. doi:10.1037/ 0033-295x.108.3.624

Brown T.L., Roos-Gilbert L., Carr T.H. Automaticity and word perception: Evidence from Stroop and Stroop dilution effects // Journal of Experimental Psychology: Learning, Memory, and Cognition. 1995. Vol.21. No.6. P.1395-1411. doi:10.1037/0278-7393.21.6.1395

Dhooge E., Hartsuiker R.J. How do speakers resist distraction? // Psychological Science. 2011. Vol.22. No.7. P. 855-859. doi:10.1177/0956797611410984

Doehrman S., Landau R., O'Connell D. The Stroop phenomenon: Perceptual conflict or response competition? // Perceptual and Motor Skills. 1978. Vol. 47. No. 3 suppl. P. 1127-1131. doi:10.2466/pms.1978.47.3f.1127

Durgin F. H. The reverse Stroop effect // Psychonomic Bulletin and Review. 2000. Vol.7. No.1. P.121-125. doi:10.3758/ bf03210730

Dyer F. N., Severance L. J. Stroop interference with successive presentations of separate incongruent words and colors // Journal of Experimental Psychology. 1973. Vol.98. No. 2. P. 438-439. doi: $10.1037 / \mathrm{h} 0034353$

Glaser M. O., Glaser W.R. Time course analysis of the Stroop phenomenon // Journal of Experimental Psychology: Human Perception and Performance. 1982. Vol.8. No.6. P. 875-894. doi:10.1037/0096-1523.8.6.875

Harrison N. S., Boese E. The locus of semantic interference in the "Stroop" color-naming task // Perception and Psychophysics. 1976. Vol. 20. No. 5. P. 408-412. doi:10.3758/bf03199423

Hasshim N., Parris B.A. Assessing stimulus-stimulus (semantic) conflict in the Stroop task using saccadic two-to-one color response mapping and preresponse pupillary measures // Attention, Perception, \& Psychophysics. 2015. Vol.77. No.8. P. 2601-2610. doi:10.3758/s13414-015-0971-9

Janssen N., Schirm W., Mahon B.Z., Caramazza A. Semantic interference in a delayed naming task: Evidence for the response exclusion hypothesis // Journal of Experimental Psychology: Learning, Memory, and Cognition. 2008. Vol.34. No. 1 P. 249-256. doi:10.1037/0278-7393.34.1.249

Kalanthroff E., Davelaar E. J., Henik A., Goldfarb L., Usher M. Task conflict and proactive control: A computational theory of the Stroop task // Psychological Review. 2018. Vol.125. No. 1. P. 59-82. doi:10.1037/rev0000083

Kinoshita S., de Wit B., Aji M., Norris D. Evidence accumulation in the integrated and primed Stroop tasks // Memory and Cognition. 2017. Vol.45. No.5. P. 824-836. doi:10.3758/ $\underline{\text { s13421-017-0701-8 }}$ 
Luo C.R. Semantic competition as the basis of Stroop interference: Evidence from color-word matching tasks // Psychological Science. 1999. Vol.10. No.1. P.35-40. doi:10.1111/ $\underline{1467-9280.00103}$

Lupker S. J., Katz A.N. Input, decision, and response factors in picture-word interference // Journal of Experimental Psychology: Human Learning and Memory. 1981. Vol. 7. No. 4. P. 269-282. doi:10.1037/0278-7393.7.4.269

Mills L., Kinoshita S., Norris D. No negative priming effect in the manual Stroop task // Frontiers in Psychology. 2019. Vol. 10. P. 1764:1-9. doi:10.3389/fpsyg. 2019.01764

Parris B.A. Task conflict in the Stroop task: When Stroop interference decreases as Stroop facilitation increases in a low task conflict context // Frontiers in Psychology. 2014. Vol.5. P. 1182:1-9. doi:10.3389/fpsyg.2014.01182

Parris B.A., Wadsley M.G., Hasshim N., Benattayallah A., Augustinova M., Ferrand L. An fMRI study of response and semantic conflict in the Stroop task // Frontiers in Psychology. 2019. Vol. 10. P. 2426:1-12. doi:10.3389/fpsyg.2019.02426

Riley E., McMahon K.L., de Zubicaray G. Long-lasting semantic interference effects in object naming are not necessarily conceptually mediated // Frontiers in Psychology. 2015. Vol. 6. P. 578:1-14. doi:10.3389/fpsyg.2015.00578

Schmidt J.R. Evidence against conflict monitoring and adaptation: An updated review // Psychonomic Bulletin and Review. 2018. Vol. 26. No. 3. P. 753-771. doi:10.3758/s13423-018-1520-Z

Schmidt J. R., Cheesman J., Besner D. You can't Stroop a lexical decision: Is semantic processing fundamentally facilitative? // Canadian Journal of Experimental Psychology / Revue canadienne de psychologie expérimentale. 2013. Vol.67. No.2. P.130-139. doi:10.1037/a0030355

Schmidt J.R., Hartsuiker R. J., Houwer J.D. Interference in Dutch-French Bilinguals // Experimental Psychology. 2018. Vol.65. No.1. P. 13-22. doi:10.1027/1618-3169/a000384

Servant M., Montagnini A., Burle B. Conflict tasks and the diffusion framework: Insight in model constraints based on psychological laws // Cognitive Psychology. 2014. Vol.72. P. 162-195. doi:10.1016/j.cogpsych.2014.03.002

Sharma D., McKenna F.P. Differential components of the manual and vocal Stroop tasks // Memory and Cognition. 1998. Vol.26. No. 5. P. 1033-1040. doi:10.3758/bf03201181

Shichel I., Tzelgov J. Modulation of conflicts in the Stroop effect // Acta Psychologica. 2018. Vol. 189. P.93-102. doi:10.1016/j. actpsy.2017.10.007
Stafford T., Gurney K.N. Additive factors do not imply discrete processing stages: A worked example using models of the Stroop task // Frontiers in Psychology. 2011. Vol.2. P.287: 1-9. doi:10.3389/fpsyg.2011.00287

Starreveld P.A., Heij W.L. Picture-word interference is a Stroop effect: A theoretical analysis and new empirical findings // Psychonomic Bulletin and Review. 2016. Vol.24. No.3. P. 721-733. doi:10.3758/s13423-016-1167-6

Steinhauser M., Hübner R. Distinguishing response conflict and task conflict in the Stroop task: Evidence from ex-Gaussian distribution analysis // Journal of Experimental Psychology: Human Perception and Performance. 2009. Vol.35. No. 5. P. 1398-1412. doi:10.1037/a0016467

Stroop J.R. Studies of interference in serial verbal reactions // Journal of Experimental Psychology. 1935. Vol. 18. No.6. P. 643-662. doi:10.1037/h0054651

Tzelgov J. Automatic but conscious: That is how we act most of the time // The Automaticity of Everyday Life. Advances in social cognition / R.S. Wyer, T.K. Srull (Eds.). Urbana-Champaign: University of Illinois, 1997. Vol. 10. P. 217-230.

van Veen V., Carter C.S. Separating semantic conflict and response conflict in the Stroop task: A functional MRI study // NeuroImage. 2005. Vol.27. No.3. P.497-504. doi:10.1016/j. neuroimage.2005.04.042

Verguts T., Notebaert W. Hebbian learning of cognitive control: Dealing with specific and nonspecific adaptation // Psychological Review. 2008. Vol.115. No.2. P.518-525. doi:10.1037/0033-295X.115.2.518

Verguts T., Notebaert $W$. Adaptation by binding: a learning account of cognitive control // Trends in Cognitive Sciences. 2009. Vol. 13. No. 6. P. 252-257. doi:10.1016/j.tics.2009.02.007

Wadsley M. An fMRI and TMS investigation of response, semantic, and task conflict in the Stroop task. PhD dissertation. Bournemouth University, 2019. URL: http://eprints.bournemouth. ac.uk/31760/1/WADSLEY\%2C\%20Michael M.Res. 2018.pdf.

Wendelken C., Ditterich J., Bunge S. A., Carter C. S. Stimulus and response conflict processing during perceptual decision making // Cognitive, Affective, and Behavioral Neuroscience. 2009. Vol. 9. No. 4. P. 434-447. doi:10.3758/cabn.9.4.434 